\title{
School Type and the Choice of Christian Religious Knowledge Among Senior Secondary School Students in Cross River State, Nigeria
}

\author{
Monity, Flora Michael (PhD) \\ Department of Curriculum and Teaching University of Calabar, \\ Cross River State, Nigeria. \\ floramonity@yahoo.com \\ Udumo,Bassey Obeten(PhD) \\ Department of Environmental Education University of Calabar \\ Basseyobeten9@gmail.com \\ Igwebuike, Osedumme (PhD) \\ Department of Curriculum and Teaching University of Calabar, \\ Cross River State, Nigeria. \\ osedumme83@gmail.com or osedumme igwebuike@yahoo.com
}

\begin{abstract}
This research work evaluated the influence of school type on the choice of Christian Religious Knowledge in secondary schools in Cross River State. To achieve the purpose of the research, one research questions was put forward and transformed into one null hypotheses. A brief review of related literature was undertaken with reference to the variable under study. The ex-post facto research design was adopted for achieving the purpose of this study and the simple random sampling technique was adopted in selecting the ten (10) local government areas used for the study. The proportionate simple random sampling technique was adopted in selecting the fifty four (54) secondary schools and the seven hundred and three (703) senior secondary two students used for the study. A structured questionnaire titled School Type and Choice of Christian Religious Knowledge questionnaire (STCCRKSQ) was the instrument used for collection of data in the study. The reliability of the research instrument was established through the Cronbach Alpha reliability method. Chi-square statistical tool was used for data analysis. The findings obtained from analysis of data and hypotheses testing indicated that there was no significant influence of school type on students' choice of Christian Religious Knowledge in the study area. It was concluded that students should be independent when it comes to making choice of subject. Based on these findings it was recommended among others that senior secondary school students from both public and private schools should be properly counseled on the relevance of studying any subject in order to promote their choice. Keywords: School type, choice of subject,Christian Religious Knowledge secondary school Students, Cross River State.
\end{abstract}

DOI: $10.7176 /$ RHSS/9-22-09

Publication date: November $30^{\text {th }} 2019$

Introduction

In education, whether formal or informal, the success of every student depends on the subjects or skills he chooses to offer. Human reasoning, hopes, aspirations, attitude and values are thus generally known to depend largely on the choice one makes. The degree of importance this variable (choice of subjects) hold on contemporary educational system, has motivated scholars to carry an in-depth studies, on how to make secondary school students make choice of subjects to offer without the influence of external variables (Hewitt, 2010).

The purpose of education is said to be attained when students are given the liberty to choose subjects which reflect their ability, capability and interest. However, the case of some Christian Religious Knowledge is quite peculiar in the sense that senior secondary school students are being influenced by some variables. According to Kasomo (2011), during the colonial era, Christian Religious Knowledge was a dominant school subject in the time table. This was because the missionaries used it as a tool to have converts. Virginia Wesleyan College News (2016) outlined the four major goals of Christian Religious Knowledge to include: introducing students to the diversity of religious beliefs and values (especially those which are a powerful presence in today's world); integrating religious perspectives with various academic disciplines; encouraging personal clarification of religious beliefs, values and orientation; and preparing students for religious vocations. Dare (2006) stated that the main goal of Christian Religious Knowledge in Nigeria was to produce honest, faithful and truthful individuals, who are morally, mentally and spiritually developed to protect the society. National 
Commission for Colleges of Education (NCC, 1992) stated the national objectives of Christian Religious Knowledge as follows: (1) To express satisfactorily intellectual capacity to benefit from further education in CRK. (2) Logically reduce or resolve tension and conflict arising from interplay of traditional practices and gospel value. (3) Demonstrate sound knowledge and appreciation of the moral value needed to live as a Christian in various stages of growth and development. (4) Demonstrate professional proficiency for teaching CRK in the primary and junior secondary schools. (5) Radiate attitude and values which are typical of nature and responsible member of the Christian community such as love, respect, honesty and service. (6) Express accurately and respectfully what the various churches and religious group beliefs and practices and to eliminate prejudice and intolerance. The summary of the above NCCE objectives of Christian Religious Knowledge is to ensure moral uprightness and to adopt sound moral values.

The high level of moral decadence and insurgencies in Nigerian nation is an indication that there is poor religious teaching in secondary school system. Christian religious studies (CRS) as one of the religious subjects taught in secondary school in Nigerian takes a central position in ensuring moral and spiritual well being of individuals in the society. The key roles of CRS in equipping the individuals and ensuring high level of morality is made clear in the objectives of CRS at the senior secondary level which include; to provide more opportunities for Nigerian youths to learn more about God and thereby develop their faith in God; to enable the youths to accept Christ as their saviour; to help the youths develop Christian attitude and moral values (such as humility, respect, love, and justice, etc); to instill in the youth the spirit of tolerance, reconciliation, peaceful co existence and non-violence as well as to develop and foster in the youth the spirit of respect for all people and human life.

School type may influence the choice of CRK among senior secondary students in Cross River State. Education in Nigeria is an instrument "par excellence" for effective national development. It has witnessed active participation by government and non-governmental agencies (private). Government-owned secondary schools also called public schools are those owned and financed by the government while private schools are secondary schools owned by the communities, corporate bodies, religious organizations, individuals or establishment (Fafunwa, 2004).

Mbithe (2012) states that school type and the environment where the school is located influence choice of subject. The researcher further stated that there are schools that are mostly or specifically subject oriented, thus making it imperative for most subjects to be compulsory for students. This was supported by Truss (2016) who found that students at private schools were twice more likely than their counterparts in public schools to take physics, chemistry and three times likely to take foreign languages. The author also affirmed that students of public schools were seven times more likely than their peers in private schools to take media studies. Truss stressed that students of government owned schools were being mis-sold low quality subjects that are not accepted at top university to boost school results. Their chances of studying at top universities and entering some professions based on certain subjects are being cut off before they have even filled in the application form. It is against this background that this study is poised to investigate the influence of school type and choice of Christian Religious Knowledge among senior secondary students in Cross River State, Nigeria.

\section{Statement of the problem}

The present research was triggered by a sense of concern on number of students that eventually register for Christian Religious Knowledge in their senior secondary classes. With the current situation in Nigeria where youth of our time (both male and female) are involved in all sort of criminality ranging from cultism, terrorism, kidnapping, militancy, etc. Christian Religious Knowledge is supposed to be a dominant subject in secondary school because of its importance which are numerous. The importance may include: inculcation of good moral values, development of sound individual who are morally and spiritually upright, individual who are honest and truthful to develop the society. Despite the fact that many students enrol for Christian Religious Knowledge in their junior secondary in the state, available statistics as shown in table 1 showed a decline in their enrolment for WAEC/NECO examination. Again, looking at the performance of students on yearly basis, it would be seen that majority of the passes are concentrated on the ordinary pass not at distinction or credit level. The attitude is reflected also in negligible number of candidates seeking admission in B.Ed Christian Religious Knowledge (Kasomo, 2010).

It is on this note that the question; does school type influence choice of Christian Religious Knowledge among senior secondary students arises. The implication is that if something is not done urgently, Art subjects especially Christian Religious Knowledge might be eradicated completely from secondary school curriculum The Executive Secretary of NERDC, Prof Ismail Junaidu noted that, instant at the commencement of the 
TABLE 1

Statistics of those that enrolled for Christian Religious Knowledge and how the number decline from SS1-SS3 in Cross River State

\begin{tabular}{llll}
\hline Name of L.G.A & SS 1 & SS2 & SS3 \\
\hline Akamkpa & 747 & 513 & 680 \\
Akpabuyo & 307 & 145 & 137 \\
Bakassi & 125 & 82 & 74 \\
Biase & 637 & 475 & 443 \\
Calabar Municipality & 3046 & 1020 & 487 \\
Calabar South & 1869 & 471 & 334 \\
Odukpani & 575 & 380 & 345 \\
Abi & 505 & 375 & 354 \\
Boki & 492 & 349 & 321 \\
Etung & 153 & 99 & 62 \\
Ikom & 20 & 15 & 65 \\
Obubra & 582 & 505 & 511 \\
Yakurr & 552 & 494 & 457 \\
Bekwarra & 366 & 287 & 213 \\
Obanliku & 399 & 294 & 192 \\
Obudu & 948 & 718 & 563 \\
Ogoja & 491 & 387 & 314 \\
Yala & 740 & 515 & 429 \\
\hline
\end{tabular}

Source: Cross River State Secondary Education Board, Statistics Division (2016)

present administration, the Hon. Minister of Education sought and obtained the approval of the National Council on Education to make CRK compulsory for all Christian students and Islamic studies compulsory for their Muslim counterpart (Voice of Nigeria, 2017). This stresses the relevance of the subjects to the character building of the individual learners and national development. Unfortunately, fewer students tend to be attracted to the subject.

\section{Purpose of the study}

The major objective of the present study is to find out if school type influence choice of Christian Religious Knowledge among senior secondary school students in Cross River State.

Specifically, the study sought to establish whether:

1. School type influences choice of Christian Religious Knowledge among secondary school students.

\section{Research questions}

To give solution to the above research problems, the following research question was posed to give direction to the work.

1. How does school type influence choice of Christian Religious Knowledge among secondary school students?

\section{Statement of hypotheses}

1. There is no significant influence of school type on students' choice of Christian Religious Knowledge.

\section{Literature review}

\section{School type and choice of CRK}

School type may influence the choice of CRK among senior secondary students in Cross River State. Education in Nigeria is an instrument "per excellence" for effective national development. It has witnessed active participation by government and non-governmental agencies (private). Government-owned secondary schools also called public schools are financed by the government while private schools are secondary schools owned by the communities, corporate bodies, religious organizations, individuals or establishment (Fafunwa, 2004).

Following the government takeover of schools, Nigerian secondary school curriculum was reviewed, and more emphasis was placed on the studies of science and technological subjects which invariably affected Christian Religious Studies. This policy by government caused a drastic decline in the number of students who choose Christian Religious Knowledge among senior secondary school students. Itolondo (2012) confirmed that most of the CRK teachers were demoralized because they do not receive from the government. This shift affects 
the study and interest of students in CRK in school system leading to poor enrolment in CRK (Isukpa, 2014). Gbenda (2004) stressed that students' enrolment and interest in CRK could as well be as a result of inadequate provision of teaching aids, fewer professional teachers and lack of incentives among other things in both public and private secondary schools. The inability of government to meet its obligation of funding and regular training of public/government owned school call for patronage of private schools, as no parent will want his/her child to attend a school that is not well equipped and government presence is not felt. Kagendo (2015) also added that the problem of agriculture and other subjects selection has been brought by ineffective or inappropriate guidance and counselling, inadequate availability of school counsellors.

Ozioma (2011) pointed out that the type of school a student enrolled in has some effect on subject choice. Chubb (2015) expanciated that schools formed by religious organizations and independent schools (formed by organizations) are the second largest sector after public or government schools. These schools may be favoured for many reasons; prestige and the social status of the old school tie, better quality infrastructure and facilities. Most subjects are imposed on students depending on the ideology of the school, for those that are vocational oriented, vocational subjects are made compulsory, those owned by religious organization, Christian Religious Knowledge are imposed, etc. In confirmation of the above view Okumu (2013) maintained that the school has a great role to play in influencing students' choice of science subjects. Njoku (2009) equally adduced that poor enrolment of students in CRK could be attributed to teachers' instructional delivery system and teacher' personality.

Olamide and Olawaiye (2013) were the view that environment in which a student find him or herself has influence on the career choice visa vise choice of subject. Okumu (2013) in his study sought to find out if there were enough science facilities in the school. According to the finding, $79.47 \%$ of the students indicated that there were enough science facilities in the school and $20.53 \%$ of the students indicated that there were no enough science facilities in the school. The facilities in the school were in biology, chemistry and physics laboratories which were partially equipped, the teachers were qualified and competence. The finding has found that the majority of students choose subject based on it high quality and facilities rather than deciding based on the instructor or the ease of the class. To confirm the assertion, Mutinda (2013) also carried out a study, it was established that majority of the students from public secondary schools in Mwea division of Mbeere had positive attitude towards CRK. However, despite this positive attitude, a number of factors affect their choice of the subject. The school did not have adequate resources for teaching and learning of CRS. It is assumed that other subjects like English, mathematics, integrated science, etc. are more important than Christian Religious Studies. Therefore, more emphasis is given to those subjects. This may accounts for some reason why some teachers enrol into other professions like accounting, law, banking and finance, etc. instead of Christian Religious Knowledge (Anya, 2016).

Isukpa (2013) further stated that government decision on elective nature of the Christian Religious Knowledge in senior secondary school in Nigeria equally reduce the number of student that register for the subject in West African Examination Council (WAEC) and National Examination Council (NECO) as well as other internal examination. Anya (2017) still maintained that many people and religious organizations now protested against government neglect of religious studies. Such organization like Christian Association of Nigeria (CAN) has frowned over government poor attitude towards the study of Christian Religious Knowledge in schools. The organization franked at the low level of morality in the country, and emphasised on the spiritual upbringing of your children. The author continued that they do not mean that science and technology should not be given adequate place in our education system, but it would be a grave mistake to operate a system of education that is focused on technology, science and materialism at the expense of religious education. It further stressed that however, the important of religion to a large extent can be buttressed referring to the statement credited to the Emir of Kano in 1989 which remarked that Nigerian child may grow without sufficient moral base if adequate arrangement are not made for the inclusion of religious and moral instruction in the universal free primary education up to tertiary institution. He emphasized that the absent of such arrangement will lead to moral decay of the Nigeria youth and the nation at large (Anya, 2016).

\section{Methodology}

The ex-post facto research design was adopted for the study. The aim was to determine the variables under study influence the dependent variable.

The study was carried out in Cross River State. Cross River State which is made up eighteen (18) local government areas which is divided into three education zones of Calabar, Ikom and Ogoja. The population of this study consisted of all senior secondary school students in public and private secondary schools in Cross River State. Statistics from the Cross River State Ministry of Education shows a population of 27,890. 
TABLE 2

Distribution of senior secondary school students in public and private secondary schools by local government areas in Cross River State

\begin{tabular}{|c|c|c|c|c|c|}
\hline \multirow[t]{2}{*}{$\mathrm{S} / \mathrm{N}$} & \multirow[t]{2}{*}{ LGA } & \multirow{2}{*}{$\begin{array}{ll}\begin{array}{l}\text { No. } \\
\text { schools }\end{array} & \text { of }\end{array}$} & \multicolumn{2}{|c|}{ No. of students } & \multirow[t]{2}{*}{ Total } \\
\hline & & & Male & Female & \\
\hline 1. & Akamkpa & 18 & 981 & 959 & 1940 \\
\hline 2. & Akpabuyo & 6 & 334 & 345 & 679 \\
\hline 3. & Bakassi & 3 & 175 & 162 & 337 \\
\hline 4. & Biase & 16 & 814 & 741 & 1555 \\
\hline 5. & Calabar Municipality & 16 & 1909 & 2644 & 4553 \\
\hline 6. & Calabar South & 7 & 1223 & 2451 & 2674 \\
\hline 7. & Odukpani & 15 & 713 & 681 & 1400 \\
\hline 8 & Abi & 12 & 618 & 616 & 1234 \\
\hline 9 & Boki & 30 & 564 & 623 & 1187 \\
\hline 10 & Etung & 12 & 204 & 146 & 350 \\
\hline 11 & Ikom & 19 & 1305 & 879 & 2185 \\
\hline 12 & Obubra & 19 & 896 & 709 & 1605 \\
\hline 13 & Yakurr & 17 & 923 & 600 & 1523 \\
\hline 14 & Bekwara & 6 & 561 & 325 & 886 \\
\hline 15 & Obanliku & 13 & 482 & 403 & 885 \\
\hline 16 & Obudu & 26 & 1232 & 997 & 2229 \\
\hline 17 & Ogoja & 14 & 683 & 509 & 1192 \\
\hline 18 & Yala & 20 & 766 & 718 & 1484 \\
\hline Total & & 269 & 14,384 & 13,514 & 27,898 \\
\hline
\end{tabular}

Source: Cross River State Secondary Education Board, 2018

Simply random sampling was used to select the sample. The sample for the study was of seven hundred and three (703) senior secondary school two (SSS 2) students. Instrument for data collection was a questionnaire tagged Peer Influence and Choice Christian Religious Knowledge Questionnaire (PICCRKQ) which was constructed by the researchers and validation ascertained.

The reliability was determined using Cronbach alpha and the result obtained ranged between .724 and .843 which showed high reliability of the research instrument.

\section{Results}

Hypothesis one

School type has no significant influence on students' choice of Christian Religious Knowledge. The independent variable in this hypothesis is school type which is categorized into public and public schools while the dependent variable is students' choice of Christian Religious Knowledge which is categorized into Yes and No options. Chi-square statistical tool was used for data analysis. The result of this analysis is presented in Table 3 .

As presented in Table 3, the result of analysis of hypothesis six showed that the calculated $\mathrm{X}^{2}$ value of.164 is less than the critical $\mathrm{X}^{2}$ value of 3.84 at 0.05 level of significance with 1 degree of freedom. This implied that the null hypothesis was upheld. Therefore, there is no significant influence of school type on students' choice of Christian Religious Knowledge (CRK) in Cross River State. 
TABLE 3 Chi-square analysis of the influence of school type on students' choice of Christian Religious Knowledge in secondary schools in Cross River State

\begin{tabular}{llllll}
\hline School type & Choice of CRK & & Total & Chi-square & Sig. \\
\hline & Yes $(\%)$ & No $(\%)$ & & & \\
Public & $184(49.86)$ & $185(54.21)$ & 369 & .164 & .685 \\
Private & $159(48.33)$ & $170(51.67)$ & 329 & & \\
\hline
\end{tabular}

Not significant at $0.05 ; \mathrm{df}=1$; Critical $\mathrm{X}^{2}=3.84$

The result further revealed that 184 students representing 49.86 percent of students from public schools were offering Christian Religious Knowledge while 185 representing 50.14 percent were not offering the subject. Again, the result also showed that 159 students representing 48.33 percent of students from private schools were offering Christian Religious Knowledge while 170 representing 51.67 percent of the students were not offering the subject in private secondary schools in the study area. This result showed that students from public and private secondary schools did not differ significantly in their choice in the subject in the study area.

\section{Discussion of findings}

This section of this work presented the discussion of results obtained in the study based on the hypothesis formulated for the study

\section{School type and students' choice of CRK}

The report of finding showed that the calculated $\mathrm{X}^{2}$ value of .164 is less than the critical $\mathrm{X}^{2}$ value of 3.84 at 0.05 level of significance with 1 degree of freedom. The implication of this finding is that there is no significant influence of school type on senior secondary school students' choice of Christian Religious Knowledge in secondary schools in Cross River State. This result could be attributed to the fact that students from both public and private schools require the same subject combination to qualify for admission into their dream career at the tertiary level of education. This could be the reason why there is no significant influence of school type on students' choice of Christian Religious Knowledge.

The finding of this study is in disagreement with the finding of Ozioma (2011) which reported that the type of school a student enrolled in has some effect on subject choice. Chubb (2015) maintained that schools established by religious organizations and independent schools (formed by organizations) are the second largest sector after public or government schools. These schools may be favoured for many reasons; prestige and the social status of the old school tie, better quality infrastructure and facilities. Most subjects are imposed on students depending on the ideology of the school, for those that are vocational oriented, vocational subjects are made compulsory, those owned by religious organization, Christian Religious Knowledge are imposed, etc. In confirmation of the above view Okumu (2013) maintained that the school has a great role to play in influencing students' choice of science subjects. The finding of this study also supported the finding of Isukpa (2013) which stated that government decision on elective nature of the Christian Religious Knowledge in senior secondary school in Nigeria equally reduced the number of students that register for the subject in West African Examination Council (WAEC) and National Examination Council (NECO) as well as other internal examination. Anya (2016) still maintained that many people and religious organizations now protested against government neglect of religious studies. Such organization like Christian Association of Nigeria (CAN) has frowned over government poor attitude towards the study of Christian Religious Studies in schools. The organization stated that with the low level of morality in the country, emphasis should be laid on the spiritual upbringing of your children. The author continued that they do not mean that science and technology should not be given adequate place in our education system, but it would be a grave mistake to operate a system of education that is focused on technology, science and materialism at the expense of religious education.

\section{Conclusion}

Based on the statistical findings obtained from the study, it was concluded that there is no significant influence of school type on students' choice of Christian Religious Knowledge in public and private secondary schools in the study area.Not withstanding the type of school a student attend,he or she can aspire to any level provided there he well guided .

\section{Recommendations}

i. Senior secondary school students from both public and private schools should be properly counseled on the relevance of studying Christian Religious Knowledge in order to promote their choice of the subject. 
ii. School counsellors should ensure that students are continually guided on the need to rely less on the advice and influence of their peers in order to promote their choice of Christian Religious Knowledge.

\section{References}

Anya, C. (2016). Attitude of teachers towards teaching of Christian religious knowledge in primary schools in Onicha Local Government Area. www.eajournals.org/wp.content/education.

Chubb, J. (2015). The private school stigma: The Atlantic. https://en.mwikipedia.org >wiki>privat...

Dare, F. A. (2006). Christian Religious Knowledge as a means of achieving millennium development goals for sustainability in Nigeria. Journal of Teacher Perspective

Fafunwa, B. A. (2004). History of education in Nigeria. https://www.goodre ads.com $>$ book $>$ show.

Gbenda, H. S. (2004). Attitude of secondary school students towards the study of Christian religious studies. www.aajournal.org/wp.c ontent/uploa...

Hewitt, J. (2010). Factors influencing career choice. www.onlinecol lege.org.201 0/05/17/wy. Retrieved 28th March, 2017.

Isukpa, M. E. (2014). Effect of role play on students' academic achievement and interest in Christian Religious Knowledge in senior secondary school students in Ebonyi central education zone of Ebonyi State, Nigeria. M.Ed thesis, University of Nigeria, Nsukka.

Isukpa, M. E. (2014). Effect of role play on students' academic achievement and interest in Christian Religious Knowledge in senior secondary school students in Ebonyi central education zone of Ebonyi State, Nigeria. M.Ed thesis, University of Nigeria, Nsukka.

Itolondo, W. A. (2012). The role and status of CRE in the school curriculum in Kenya. Journal of Emerging Trends in Educational Research and Policy Studies (JETERAPS), 3 (5), 721-727.

Kagendo, K. D. (2015). Influence of choice of agricultural subject among public secondary school students in Kibirichia Divisiion, Buuri Sub-Country, Kenya. Unpublished masters thesis.

Kasomo, D. (2011). Students attitude on the teaching of Christian religious knowledge in secondary school in Kenya. International Journal of Psychology and Behavioural Science, 1 (1), 48-54.

Mbithe, N. (2012). Organizational factors affecting employee performance. https://utami.ac.ug>mastersproposals.

National Commission for Colleges of Education (NCCC, 1992). Minimum standard for Nigeria certificate on education. Abuja: Federal Government Press.

Njoku, C. N. (2009). Strategies for enhancing Christian Religious Knowledge pedagogy in secondary school in Ebonyi State. In M. E. Isukpa (2014). Effect of role play on academic achievement and interest in CRS in Ebonyi central education zone. M.Ed thesis University of Nigeria, Nsukka.

Okumu, J. O. (2013). Factors influencing choice of school subjects by senior secondary students in Oredo L.G.A. of Edo State. /project.coming/education/the.facto.... Retrieved on $21^{\text {st }}$ April, 2017.

Olamide, S. O. \& Olawaiye, S. O. (2013). Factors determining the choice of career among secondary school students. International Journal of Engineering and Science (IJES), 2 (6), 33-34.

Ozioma, C. A. (2011). Influence factor influencing attitude of students towards vocational subject in secondary school in south eastern Nigeria. Journal of Educational Research, 1 (2), 49-56.

Truss, E. (2016). A-level choice: The sharp contrast between private schools and comprehensive. https://eprints.qut.edu.au>...

Virginia Weslayan College Newsfeed (2015). www.vwc.edu $>$ Home $>a$ cademic $>$ majors $>$ Religiousstudies. Retrieved on $20^{\text {th }}$ March, 2017.

Voice of Nigeria (2017). https://mithnigerianvoice.com/News 